\title{
DETERMINANTS OF SMALLHOLDER FARMERS' ACCESS TO MOBILE PHONE BASED MONEY TRANSFER SERVICES - EVIDENCE FROM VOLTA REGION OF GHANA
}

\author{
MAXWELL AMEDI ${ }^{1 *}$, FREEDMAN DELALI WOLEDZI ${ }^{2}$ \\ ${ }^{1}$ Department of Programs, World Vision International, Ghana. ${ }^{2}$ Centre for Migration Studies (CMS), University of Ghana, Legon, Ghana. \\ Email: maxzy5050@gmail.com
}

Received: 05 April 2021, Revised and Accepted: 15 April 2021

\section{ABSTRACT}

Objective: Smallholder farmers' access to Mobile Phone Based Money Transfer Services in Akatsi North District of Volta Region of Ghana under the Planting for Food and Jobs Programme.

Methods: Primary data were collected from 300 farmers in beneficiary districts while secondary data were gathered from literatures and various actors. A multi-stage sampling technique was used in selecting respondents for the study. The first stage involved selecting ten communities that benefited from the planting for food and jobs program in the Akatsi North district, while the second stage considered randomly selecting 30 beneficiary farmers in each community. Obtained data were analyzed using Statistical Package for the Social Sciences and STATA-11 software. Results were presented in the form of descriptive statistics, cross tabulation, and Logit regression model.

Results: Majority of respondents (74\%) do not use Mobile Phone Based Money Transfer platform for any agricultural transaction. Is only 26\% of the respondents that use the mobile money platform for their agribusiness activities. Out of the nine explanatory variables included in the Logit regression model, six of them were significant at $\mathrm{p}<0.01, \mathrm{p}<0.05$, and $\mathrm{p}<0.1$. Significant factors include: Educational level of households, age, major occupation, accessibility of mobile money service provider, convenience to respondent, trust of the system, and availability of mobile money service.

Conclusions: The availability and accessibility of Mobile Phone Based Money financial services among smallholder farmers is key to achieving competitive global business.

Keyword: Agricultural financial service, Ghana, Mobile money, Smallholder farmers, Logit model, Agricultural Information and Communication Technology, Coronavirus disease-19.

(C) 2021 The Authors. Published by Innovare Academic Sciences Pvt Ltd. This is an open access article under the CC BY license (http://creativecommons. org/licenses/by/4.0/] DOI: http://dx.doi.org/10.22159/ijags.2021v9i3.41520. Journal homepage: https://innovareacademics.in/journals/index.php/ijags

\section{INTRODUCTION}

Ghana's agriculture sector contribution to Gross domestic product over the past decade has been between $10 \%$ and $35 \%$ [1]. The sector's contribution to employment in Ghana is the largest (45\%), as compared to the Service (41\%) and Industry (14\%) sectors and this makes the sector to remain the main source of livelihood for the people of Ghana [2]. As global food demand is rising, the vast majority of agribusinesses (70\%) directly procure their raw produce from smallholder farmers. Therefore, having an easier way of making financial transactions with smallholder farmers becomes relevant in this competitive global business era more especially in this time of COVID-19 pandemic era [3]

In response to these constraints, there has been proliferation of initiatives by the government and private investors in Ghana to expand access to financial services in these underserved markets through activities of microfinances and other mobile banking agents. This approach to deepening financial inclusion has helped over the years but has not completely addressed the barriers faced by rural poor farmers [4]. This is because, some literatures revealed that microfinance institutions especially the mobile bankers are mostly not regular, unfaithful and do wrong daily recordings for farmers knowing well that most of them are illiterates. The worse one is that, most of the mobile banking agents bolt farmers' monies away. These unprofessional attitudes and bitter experiences recorded by farmers make them not to trust operations of microfinance institutions and have confidence in their operations [5].
In recent time, the telecommunication (telecos) industry has experienced rapid growth in using digital and mobile phones to save money, trade, and market products and services to catch up with the ever increasing globalization trend which reduces cost, provides compelling, innovative, and irresistible experiences to customers [6]. One such technological approach that has gained so much global recognition in recent time is the Mobile Money Transfer (MMT) system which considers the poor as a viable customer's in spite of their small transaction sizes. MMT is an electronic mobile device which enables people to use their mobile telephones to manipulate their bank accounts, store value in an account linked to their handsets, and transfer funds; buy products, make payments or even access credit or insurance products [7]. Money Transfer services in Ghana have contributed greatly toward economic growth as enterprises have increased revenues, employment and innovation in the society [8]. The MMT system has been considered to be an efficient, reliable, and affordable system of saving money, sending or receiving money for payment of salaries, facilitating trade, simplify payment/settlement of business transactions, and payment of remittances from family members which can be deposited in one location and withdrawn in another location.

Literature reviewed show that though there have been few studies in Ghana on the effect of MMT service on employment, adoption of MMT, impact of mobile money on the payment system in Ghana, impact of MMT service on the socio-economic status of mobile money vendors, factors influencing the adoption of MMT, or mobile banking service no empirical studies exist on smallholder farmers' access to Mobile Phone Based Money Transfer Services in Volta Region of Ghana [9]. This 
aroused the author's inquisition to carry out the research to fill in the knowledge gap by answering the following questions to aid in effective policy formulation and implementation. The findings of the study will help in rapid uptake and modernization of mobile money services toward globalization.

\section{Rationale and novelty of study}

Few studies exist in Ghana on the effect of MMT service on employment, adoption of MMT, impact of mobile money on the payment system, impact of MMT service on the socio-economic status of mobile money vendors, factors influencing the adoption of MMT, mobile banking services however no empirical studies exist on smallholder farmers' access to Mobile Phone Based Money Transfer Services in Volta Region of Ghana.

The study is important as global food demand is rising,and the vast majority of agribusinesses $(70 \%)$ directly procure their raw produce from smallholder farmers. Therefore, having an easier way of making financial transactions with smallholder farmers becomes relevant in this competitive global business era more especially in this time of COVID-19 pandemic era. Above and beyond, this study adds to the paucity of research in agribusiness and Agricultural Finance in Ghana and serves as a framework for agricultural globalization.

\section{Research questions}

1. What proportion of small holder farmers use mobile money platform in their agricultural activities?

2. What are the determining factors which influence smallholder farmers use of MMT platform?

\section{Research objective}

The main objective of the study is to assess smallholder farmers' access to Mobile Phone Based Money Transfer Services in Volta Region, Ghana with specific objectives as;

\section{The specific objectives}

1. To analyze the proportion of small holder farmers that use mobile money platform in their agricultural activities

2. To identify and estimate the determining factors which influence smallholder farmers' use of MMT.

\section{METHODS}

The study used a mixed research approach by combining both qualitative with a quantitative research design. The use of the mixed research design allowed to cross validate the research findings. A multistaged sampling technique was used for the study. During the first stage, ten communities that benefited from the planting for food and jobs program in the Akatsi North District were randomly generated. The second step involved selecting 30 beneficiary farmers in each community randomly. In all, a total of 300 beneficiary farmers were used for this study. The data for this study were collected by trained extension officers who understand the terrain and can speak the local dialect.

The survey was conducted between Februarys and May 2020. Interviews were collected using structured questionnaire in the gathering the requisite data. Open- and close-ended questions were used. The data were processed with Statistical Packages for the Social Sciences (SPSS) and STATA -11 software.

To estimate the proportion of small scaled farmers in Akatsi North Districts that used mobile money platform in their agricultural activities, descriptive statistics was used. Percentages and cross-tabulation were used to describe the results.

To estimate the factors that influence smallholder farmers' use of mobile money, Logit Regression Model was used. In general, farmers would decide to use mobile money based platform at any given point when the combined effects of the factors assumed to influence farmers' decision to use the mobile money platform exceed the reaction threshold.
Farmers' decision to use mobile phone money transfer system assumes a binary choice model hence dichotomous. The choice of the logit model is based on argument by Long [10] that when a continuous dependent variables are included in the model, logit model is well suited for explaining and testing the hypothesis about the relationships between a categorical outcome variable and one or more categorical or continuous variable. It is also worth noting that the use of the logit model for this analysis is consistent with the literatures found in similar works (Akudugu et al. [11]; Kudugu [12]; Ololade and Olagunju [13]).

\section{Study area}

The study area as described in Fig. 1 is Akatsi North District, which happens to be one of the 260 Metropolitan, Municipal and District Assemblies in Ghana, and forms part of the 18 of Municipalities and Districts in the Volta Region. In 2012, Akatsi North District Assembly was carved out of the Akatsi District by Legislative Instrument (L.I 2161) 2016 with its capital named Ave Dakpa for the purpose of ensuring decision-making and development at the local level [1]. The district lies between latitude $S 6^{\circ}$ and $7^{\circ} \mathrm{N}$ and longitude $0 \mathrm{~W}-1 \mathrm{E}$ and south of the dry savannah and north of the forest zones. It covers an area of about $324 \mathrm{sq} \mathrm{km}$. It is located in the southeastern part of the Volta region. The District shares boundaries with Akatsi South District to the south, to the north with Adaklu District, to the west with Central Tongu District, and to the east with the Republic of Togo. The population of the District according to 2010 population and housing census stands at 33,035 with 15,126 males and 17,909 females. The total dependency ratio for the District is 56.4 and is higher for the males (94.6) than that of females (82.1). Akatsi North is entirely rural populated or a rural settlement.

The district's economy consists of agricultural, commercial, industrial, and service sectors. According to 2010 Population and Housing Census, the agricultural sector employs $67.3 \%$ of the economically active population. The main agricultural activities are crop production and livestock rearing. Farming is done on small scale and among crops cultivated include; maize, cassava, sweet potatoes, pineapples, and vegetables, such as, tomatoes, pepper, garden eggs, and okra. Despite the dominance of agriculture in the district, there are a lot of untapped potentials, such as, vast arable lands, dams, and dugouts. Livestock reared are mainly cattle, goats, sheep, and poultry. The industrial sector of the district comprises mainly agro-based activities.

\section{RESULTS AND DISCUSSION}

\section{Socio-demographic characteristics of respondents}

Sex

Results in Table 1 shows that $65 \%$ of respondents were males while females constitute (35\%). This implies that male farmers participated more in the planting for food and jobs program in Akatsi North District as compared to women. This conforms to the findings of Dzadze et al. [14] who reported that subsistence farming activity is male dominated as most activities are tedious and labor intensive.

\section{Age (years)}

The age distribution of the respondents from Table 1 shows that $39 \%$ were aged $40-49$ years and $34 \%$ were above 50 years. Results show that only $4 \%$ of respondents were below 29 years of age. The economically active labor force between 30 and 39 years were only 23\%. This shows that majority of respondents were middle-aged implying that most young ones are not into agriculture which agrees with findings from Ministry of Foreign Affairs [15] that the youth is not interested in farming. However, with the high numbers being aged, acceptance of technology could be a hindrance.

\section{Educational level}

The result from Table 1 indicates that respondents had low educational profile, $40 \%$ schooled up to primary level while $32 \%$ had no formal education. Results again show $23 \%$ of respondents attaining secondary level while only $4 \%$ was able to attain tertiary level. Inference could 
Table 1: Socio-demographic characteristics of respondents $(n=300)$

\begin{tabular}{|c|c|c|}
\hline Variables & Frequency & Totals (\%) \\
\hline \multicolumn{3}{|l|}{ Sex } \\
\hline Male & 196 & 65 \\
\hline Female & 104 & 35 \\
\hline \multicolumn{3}{|l|}{ Age (years) } \\
\hline$\leq 29$ & 11 & 4 \\
\hline $30-39$ & 69 & 23 \\
\hline $40-49$ & 118 & 39 \\
\hline$\geq 50$ & 102 & 34 \\
\hline \multicolumn{3}{|l|}{ Marital status } \\
\hline Married & 240 & 80 \\
\hline Never married & 50 & 17 \\
\hline Divorced & 10 & 3 \\
\hline \multicolumn{3}{|l|}{ Educational status } \\
\hline None & 96 & 32 \\
\hline Primary & 121 & 40 \\
\hline Secondary & 70 & 23 \\
\hline Tertiary & 13 & 4 \\
\hline \multicolumn{3}{|l|}{ Major occupation } \\
\hline Farming & 231 & 77 \\
\hline Trading & 46 & 15 \\
\hline Artisan & 20 & 7 \\
\hline Government worker & 3 & 1 \\
\hline \multicolumn{3}{|c|}{ Farming experience (years) } \\
\hline$\leq 5$ & 22 & 7 \\
\hline $6-11$ & 26 & 9 \\
\hline $12-17$ & 68 & 23 \\
\hline $18-23$ & 136 & 45 \\
\hline$\geq 24$ & 48 & 16 \\
\hline \multicolumn{3}{|l|}{ Farm size (Ha) } \\
\hline$<2.0$ & 136 & 45 \\
\hline $2.1-4.0$ & 96 & 32 \\
\hline $4.1-6.0$ & 43 & 14 \\
\hline$>6$ & 25 & 8 \\
\hline \multicolumn{3}{|l|}{ Monthly income (GHS) } \\
\hline$<100$ & 123 & 41 \\
\hline $100-500$ & 98 & 33 \\
\hline $501-1000$ & 49 & 16 \\
\hline$>1000$ & 30 & 10 \\
\hline
\end{tabular}

Source: Field Survey, 2020

be drawn from the study that majority of respondents dropped out of school and seriously into farming. This level of education has influence on adoption of mobile money technology adoption by respondents.

\section{Marital status}

Results in Table 1 shows that $80 \%$ were married and 3\% were divorced. This indicates that the majority of the people were married and have children. Findings conform to [16] which states that majority of farmers in rural areas get married before the age of 40 years.

\section{Major occupation}

Majority (77\%) of the respondents from Table 1 were farmers while $22 \%$ were engaged in trade, artisan, government work, and other types of occupation. This conforms to the assertion of Duncombe [17] that less government work exist in rural areas hence majority of them are farmers.

\section{Annual income (general household survey [GHS])}

Results from Table 1 indicates that $41 \%$ of respondents earn monthly income lesser than $100 \mathrm{GHS} /$ month. Finding show 33\% of respondents earn between 100 and 500 GHS in a month. This shows that due to the subsistence nature of respondents' activities they do not earn much.
Table 2: Ownership of mobile phone and use of mobile money platform by respondents

\begin{tabular}{|c|c|c|c|c|c|}
\hline \multirow[t]{2}{*}{ Sex } & \multicolumn{2}{|c|}{$\begin{array}{l}\text { Do you have your } \\
\text { own mobile phone? }\end{array}$} & \multicolumn{2}{|c|}{$\begin{array}{l}\text { Mobile money } \\
\text { platform use }\end{array}$} & \multirow[t]{2}{*}{ Total } \\
\hline & Yes & No & Yes & No & \\
\hline Male & $189(63 \%)$ & $7(3 \%)$ & $60(20 \%)$ & $136(45 \%)$ & 196 \\
\hline Female & $100(33 \%)$ & $4(1 \%)$ & $17(6 \%)$ & 87 (29\%) & 104 \\
\hline Total & $289(96 \%)$ & $11(4 \%)$ & 77 (26\%) & $223(74 \%)$ & 300 \\
\hline
\end{tabular}

Ownership of mobile phone and use of mobile money platform

The result from Table 2 shows that, $96 \%$ of respondents have mobile phone while $4 \%$ do not have phone. Finding from the table revealed $74 \%$ of respondents do not use mobile money platform for any transaction in Akatsi North District of Ghana for their agricultural activities. Is only $26 \%$ of the respondents that use mobile money platform for their agribusiness activities. This phenomenon is typical of rural households where majority spend greater portion of their time in farming activities [18]

Factors influencing smallholder farmers use of MMT platform

The Logit regression model assumes a random variable which predicts the probability of smallholder farmers' use of MMT platform. The model is based on cumulative logistic probability functions. For estimation purposes, the Logit regression model is specified as:

$$
\mathrm{Y}_{i}=\ln \left(P_{\mathrm{i}}\right)=\beta 0+\beta \mathrm{iX}_{\mathrm{i}}+\varepsilon_{\mathrm{i}}(1-P \mathrm{i})
$$

Where;

$\mathrm{Y}_{i}=$ Dependent variable;

$\ln \left(P_{\mathrm{i}}\right)=$ Denotes the log odds of the probability that the farmer will invest in mobile money device $(1-P \mathrm{i})$;

$P i=$ Denotes the probability of using MMT platform;

$(1-p \mathrm{i})=$ Denotes the probability of not using of MMT platform;

$\beta_{\mathrm{i}=}$ Denote the coefficients of the explanatory variables;

$\mathrm{X}_{\mathrm{i}}=$ The explanatory variables;

$\varepsilon_{\mathrm{i}}=$ The error terms.

The choice of variables for this study is based on literature (GSMA [19], Hinson [20], Davis and Venkatesh [21], Jack and Suri [22], Banstola [23]).

The descriptions of variables are presented below and the empirical model is specified in equation (2)

The a priori expectation for each variable is either negative or positive. The positive a priori expectation means that with an increase in the variable on the use of mobile money platform is expected to increase; vice versa for the negative. Nine variables were modeled as a function of farmer-specific socioeconomic, demographic characteristics, and external variables. STATA 11 software was used to estimate the parameters. The expected signs of their coefficients were predicted (a priori) based on past studies and economic theories.

\section{MMPU $=\beta 0+\beta 1 \mathrm{EDU}+\beta 2 \mathrm{AGE}+\beta 3 \mathrm{MOCCU}+\beta 4 \mathrm{MINCO}+\beta 5 \mathrm{ACCESS}+$ $\beta 6$ CONVENIECE $+\beta 7$ TRUST $+\beta 8$ AVAIL $+\beta 9$ USEFUL $+\varepsilon i$}

Factors influencing farmers to use mobile money platform in their agricultural activities

Results in Table 3 shows the factors that influence smallholder farmers use of MMT platform in the Akatsi North District of Volta Region. The direction of the coefficient of all the explanatory variables conforms to their a priori expectations. A total number of 300 farmers were used for the analysis. The McFadden $\mathrm{R}^{2}$ value of 0.8296 means that about $82.96 \%$ of variations in the dependent variable was explained by the independent variables, indicating relatively high explanatory power of the model. The F-value (Prob $>$ F) of 0.0037 implies that the model is significant at $1 \%$ or is significantly different from the critical value of $F$ at 9 and 111 degrees 
of freedom for numerator and denominator, respectively, at significance level of $<1 \%$. Six of the variables were significant whiles the rest three were not significant. The significant variables include: Educational level of households, age, major occupation, accessibility of mobile money service provider, convenience to respondent, trust of the system, and availability of mobile money service.

\section{Educational level (EDU)}

The marginal effect of educational level of respondents (EDU) which is -0.017 means that, an additional level in educational level of respondents will increase the willingness of respondents' to use mobile money platform by 1.7\%. This affirms findings from Table 1 that about $72 \%$ of the respondents schooled up to primary level. If respondent's educational level was to be a bit higher, the use of the mobile money platform would have increased. This confirms the conclusion made by Gencer [16] in his study that less educated people are more reluctant they are to use technology. The level of education has a high influence on the willingness to adapt something new compared to traditional values of the customers Bank of Ghana [3] also pointed out that consumers' knowledge of a service has a significantly positive effect on their perceived ease to use. Farmers knowledge can help identify what mobile payment can do for them, and why the services are important to them. Customers will use mobile payments easily and efficiently if they have high level of knowledge.

\section{Age (AGE)}

Also has an inverse relationship with respondents' willingness to use the mobile money platform. The marginal effect of -0.560 means that, the older the respondent the more likely it is to decrease the willingness to use any of the mobile money platform by $56 \%$. This is in line with the socio-economic results which identified the modal ages to fall within 40-49 years and above 50 years. This is supported argument made by Duncombe [17] in their study of "a risk perception on the use of electronic payment systems by young adult in Malaysia" where $97 \%$ of the respondents are below the age of 50 years.

Table 3: Logit regression result of factors influencing farmers to use mobile money platform in their agricultural activities

\begin{tabular}{lllll}
\hline \multicolumn{4}{l}{ Dependent Variable: Mobile Money Platform use (MMPU) } \\
\hline Variables & Coefficient & Std. error & p-value & Marginal effect \\
\hline Edu & $0.08137^{* *}$ & 0.03393 & 0.04154 & 0.017 \\
Age & $-0.01033^{*}$ & 0.00268 & 0.06723 & -0.560 \\
Moccu & $-0.01013^{* * *}$ & 0.00614 & 0.00013 & -0.384 \\
Minco & $0.07702^{*}$ & 0.04153 & 0.07863 & 0.269 \\
Access & $-0.00002^{* *}$ & 0.04006 & 0.04356 & -0.083 \\
Convenience & 0.01181 & 0.09017 & 0.10564 & 0.009 \\
Trust & 0.06526 & 0.6080 & 0.11451 & 0.866 \\
Avail & $-0.01666^{*}$ & 0.5194 & 0.08473 & -0.421 \\
Useful & 0.01754 & 0.08053 & 0.21372 & 0.072 \\
\hline
\end{tabular}

Number of obs $=300$, Mc Fadden $\mathrm{R}^{2}=0.8296$. Prob $>\mathrm{F}=0.0037,{ }^{* * *} \mathrm{p}<0.01$, ${ }^{* *} \mathrm{p}<0.05$ and ${ }^{*} \mathrm{p}<0.1$. Source: Field Survey, 2020

\section{Major occupation (Moccu)}

Respondents having different occupations apart from farming will have higher intention of using mobile money payment platforms for remittances. However, from the study, $77 \%$ of respondents were farmers hence recorded an inverse relationship with a marginal effect of -0.384 meaning that engaging in farming activities will lead to a decrease in the willingness to use mobile money platform by $38 \%$

\section{Monthly income (Minco)}

The results from logistic regression of factors influencing farmers use of mobile money platform in agricultural activities recorded a marginal effect of 0.269 meaning that if respondents are able to increase income it will result in $27 \%$ increase of respondents willing to use the mobile money platform. Results from the study might be attributed to the fact that $41 \%$ of respondents earn monthly income lesser than $100 \mathrm{GHS} /$ month and 33\% between 100 and 500 GHS in a month. Results could also further be explained from seasonal nature of agricultural activities resulting in irregular cash flow from their faming activities.

\section{Accessibility of vendors (Access)}

Customer's feeling is key about the accessibility of a new service to provide many benefits for them and to help improve their job performance when using the service [3]. For farmer's to be able to use mobile money platform for their farming transactions, accessibility of

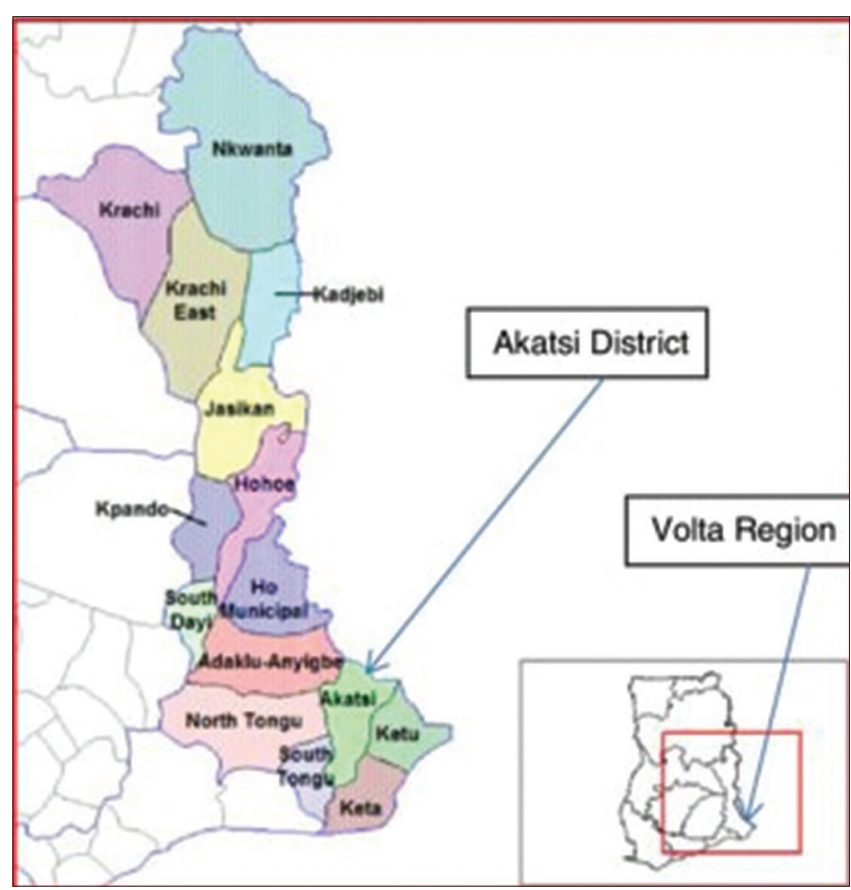

Fig. 1: Map of Akatsi North District. Source: Ghana Statistical Service, 2020

Table 4: Description of the variables used in the regression model

\begin{tabular}{|c|c|c|c|}
\hline Variables & Description & Measurements & A-piori expectation \\
\hline MMPU & Mobile Money Platform Use & Either $(0$ or 1$)$ & \pm \\
\hline EDU & Formal educational level attained & Years & \pm \\
\hline AGE & Age of beneficiaries & Years & + \\
\hline MOCCU & Major Occupation of respondent & $1=$ farming $0=$ otherwise & \pm \\
\hline MINCO & Monthly income & GHS & + \\
\hline ACCESS & access to mobile money vendors & $1=$ Yes; $0=$ otherwise & \pm \\
\hline CONVENIECE & ease and the comfort of use & $1=$ Yes; $0=$ otherwise & \pm \\
\hline AVAIL & availability of mobile money service provider & $1=$ Yes; $0=$ otherwise & \pm \\
\hline USEFUL & Usefulness of the new services & $1=$ Yes; $0=$ otherwise & \pm \\
\hline
\end{tabular}


vendors becomes important if farmers themselves do not have access to phone. The result from Table 4 shows that $96 \%$ of respondents have mobile phone while $4 \%$ do not have phone. The results further indicates that though some have phones, $74 \%$ of respondents do not use mobile money platform for any transaction in their farming transactions. Farmer's indicated during our focus group discussion that that, the services are not closer to them and some of them also admitted their challenge in using their phones for such services. The findings are in agreement with the study by [7]. Accessibility from the study had inverse relationship with the willingness of farmers to use the mobile money platform. The marginal effect of accessibility which is -0.083 means that, most respondents are not able to locate vendors within their vicinity hence a further increase in the number of respondents who are not able to locate. A further challenge in accessing the vendors in the district will result in 8\% decrease in farmers' willingness to use the mobile money platform

\section{Availability of vendors (Avail)}

Many vendors have to be available to enable farmers use the mobile money platform for their farming transactions. The marginal effect of availability which is -0.421 means that, limited vendors exist in Akatsi North District to bridge financial inclusion gap. A further increase in unavailability of vendors in the district will result in $42 \%$ decrease in farmers' willingness to use the mobile money platform

\section{CONCLUSION}

The availability and accessibility of financial services among smallholder farmers have suffered setback since the past decade. However, the revolution of MMT services in Ghana has brought an opportunity to ease the constraint of access to agricultural financial services in this competitive global business era.

The study examined Smallholder farmers' access to Mobile Phone Based Money Transfer Services in Akatsi North district of Volta Region of Ghana under the planting for food and jobs program. Findings of the study revealed that, out of the 300 farmers interviewed, $74 \%$ of them do not use mobile money platform for any agricultural transaction. Is only $26 \%$ of the respondents that use mobile money platform for their agribusiness activities.

Out of the nine variables modeled to determine the factors that influencing farmers to use mobile money platform in their agricultural activities Six of the variables were significant whiles the remaining three were not significant. The significant variables include: Educational level of households, age, major occupation, accessibility of mobile money service provider, convenience to respondent, trust of the system, and availability of mobile money service

Based on the findings from the study, the following recommendations are therefore suggested;

Because farmer's rate of usage of the mobile money platform is still low, aggressive awareness and financial literacy training programs must be deployed by the government to the populace and the benefits of the systems as a superior alternative to cash payment systems must be emphasized.

Since most active users of the platform are below the age of 39 years, the government should rely on this section of the population to drive the use of mobile money platform in Ghana.

Since occupation, educational level, availability, and accessibility of vendors have been recognized to influence the use of the mobile money platform, government need to as a matter of urgency take the campaign for the diffusion of mobile money systems into agricultural activities considering the numerous benefits it brings farmers.

Government and financial institutions in Ghana should continue to leverage on the significant socio-economic (education, age, and occupation) factors to drive mobile money platform usage.

It is also recommended that government and Fintech companies should investment in technological infrastructure support across the country to help farmers who mostly located in rural and remote areas. This will align with policymakers' agenda to increase financial outreach and improve financial inclusion by using mobile technologies

\section{REFERENCES}

1. Ghana Statistical Service: Ghana Census of Agriculture; 2017. Available from: https://www.statsghana.gov.gh/headlines.php?slidelocks=MTk 3OTM1NjUyOC4yMzc1/headlines/s41544nq09. [Last accessed on 2021 Apr 15].

2. GSMA. Country Overview; Ghana Driving Mobile-enabled Digital Transformation. Vol. 5. GSMA; 2017. p. 6-8.

3. Bank of Ghana. Mobile Financial Services in Ghana, Technical Paper Presented at Sub-Regional Workshop on Mobile Money in West Africa. Available from: https://www.theigc.org/wp-content/uploads/2016/03/ Ghana.pdf. [Last accessed on 2021 Apr 15].

4. Bank of Rwanda. Impact of Mobile Money on the Payment System in Ghana: An Econometric Analysis. Vol. 4. Bank of Rwanda; 2017. p. 2.

5. Amedi M, Dumayiri M, Mohammed AS. Loan repayment and its implication on agricultural financing in ghana-the case of MiDA agriculture program. Int J Agric Manag Dev 2019;9:391-408.

6. Asongu SA, Nwachukwu JC. The role of governance in mobile phones for inclusive human development in Sub-Saharan Africa. Technovation 2016;55:1-13

7. Au YA, Kauffman RJ. The economics of mobile payments: Understanding stakeholder issues for an emerging financial technology application. Electron Commerce Res Appl 2008;7:141-64.

8. Hughes L. M-PESA: Mobile money for the "unbanked" turning cellphones into 24-hour tellers in Kenya. Innov Technol Gov Glob 2007;2:63-81.

9. Diniz EH, de Albuquerque PJ, Cernev AK. Mobile money and payment: A literature review based on academic and practitioner-oriented publications. GlobDev 2011;4:1-3.

10. Long JS. Regression Models for Categorical and Limited Dependent Variables. Advanced Quantitative Techniques in the Social Sciences No. 7. Thousand Oaks, CA: Sage Publications; 1997. p. 10-15.

11. Akudugu MA, Guo E, Dadzie SK. Adoption of modern agricultural production technologies by farm households in Ghana: What factors influence their decisions? J Biol Agric Healthc 2012;2:1-13.

12. Kudugu MA. Estimation of the determinants of credit demand by farmers and supply by rural banks in Ghana's Upper East Region. Asian J Agric Rural Dev 2012;2:189-200.

13. Ololade RA, Olagunju FI. Determinants of access to credit among rural farmers in Oyo State, Nigeria. Glob J Sci Front Res Agric Vet Sci 2013;13:17-22.

14. Dzadze P, Mensah JO, Aidoo R, Nurah GK. Factors determining access to formal credit in Ghana: A case study of smallholder farmers in the Abura-Asebu Kwamankese district of Central Region of Ghana. J Dev Agric Econ 2012;4:416-23.

15. Kuwornu JK, Ohene-Ntow ID, Asuming-Brempong S. Agricultural credit allocation and constraint analyses of selected maize farmers in Ghana. Br J Econ Manag Trade 2012;2:353-74.

16. Gencer M. The mobile money movement: Catalyst to jump-start emerging markets. Innov Technol Gov Glob 2011;6: 101-17.

17. Duncombe R. An evidence-based framework for assessing the potential of mobile finance in sub-Saharan Africa. J Mod Afr Stud 2012;50: 369-95.

18. Khraim HS, Al Shoubaki YE, Khraim AS. Factors affecting Jordanian consumers adoption of mobile banking services. Int J Bus Soc Sci 2011;2:1-2.

19. GSMA. Market Size and Opportunity in Digitising Payments in Agricultural Value Chains. Vol. 30. London, United Kingdom: GSMA; 2016. p. 1-9.

20. Hinson RE. Banking the poor: The role of mobiles. J Financ Serv Market 2011;15:320-33.

21. Davis D, Venkatesh V. A theoretical extension of the technology acceptance model. Manag Sci 2000;46:186-204.

22. Jack W, Suri T. Mobile money: The economics of M-PESA (No. w16721). Natl Bureau Econ Res 2011;18:161-86.

23. Banstola A. Prospects and challenges of E-banking in Nepal. J Nepalese Bus Stud 2007;4:96-104. 